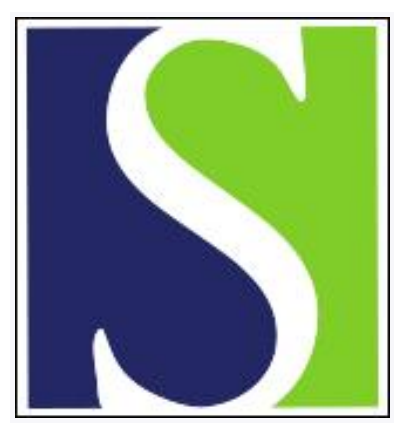

Scand J Work Environ Health 1984;10(2):99-102

https://doi.org/10.5271/sjweh.2352

Issue date: Apr 1984

Monitoring exposure to propylene oxide through the determination of hemoglobin alkylation.

by Osterman-Golkar S, Bailey E, Farmer PB, Gorf SM, Lamb JH

This article in PubMed: www.ncbi.nlm.nih.gov/pubmed/6474107

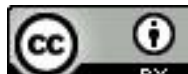




\title{
Monitoring exposure to propylene oxide through the determination of hemoglobin alkylation
}

\author{
by Siv Osterman-Golkar, PhD, ${ }^{1}$ Eric Bailey, $\mathrm{PhD},{ }^{2}$ Peter B Farmer, $\mathrm{PhD},{ }^{2}$ Susan M Gorf, BSc, ${ }^{2}$ \\ John H Lamb²
}

\begin{abstract}
OSTERMAN-GOLKAR S, BAILEY E, FARMER PB, GORF SM, LAMB JH. Monitoring exposure to propylene oxide through the determination of hemoglobin alkylation. Scand $J$ Work Environ Health 10 (1984) 99-102. The levels of $N^{r}$-(2-hydroxypropyl)histidine in hemoglobin were determined for eight employees of a plant where propylene oxide is used and for thirteen referents. Good agreement was obtained between the estimated exposure and the degree of alkylation of hemoglobin; values of $0.1 \mathrm{nmol}$ (11 referents), $0.2 \mathrm{nmol}$ (1 referent), $0.38 \mathrm{nmol}$ (1 referent), $0.2 \mathrm{nmol}$ (1 employee without exposure), $0.85-1.2 \mathrm{nmol}$ ( 3 employees with low-intermediate exposure), and $4.5-13 \mathrm{nmol}$ (4 employees with high exposure; 10 ppm propylene oxide during $25-75 \%$ of the work time) per gram of hemoglobin were recorded. The method gives a measure of the in vivo dose obtained during a period of about four months and is therefore superior to point measurements of concentrations for the surveillance of exposure conditions in work environments.
\end{abstract}

Key terms: dosimetry.

Propylene oxide is used industrially as an intermediate in the preparation of polyurethane foam and polyester resins and in the preparation of lubricants, surfactants, and oil demulsifiers. This alkylating agent is also extensively used as a fumigate for stored agricultural products, as a soil sterilant, and as a plastic monomer in electron microscopy. Propylene oxide has approximately the same chemical reactivity as the analogous compound ethylene oxide, and the two compounds have accordingly a similar mutagenic effectiveness $(7,10)$. Propylene oxide has been shown to be carcinogenic in rats and mice $(3,4,5,14)$. The widespread use and demonstrated genotoxicity of the compound makes the surveillance of exposed populations an important matter.

Exposure to alkylating agents can be monitored by the measurement of their reaction products with nucleophilic groups of macromolecules in vivo $(1,6$, $8,11)$. Deoxyribonucleic acid (DNA) is generally recognized as the main target in the mutagenic and cancer-initiating action of electrophilic reagents. Measurements of products of reaction with DNA present, however, difficulties due to the restricted availability of DNA in human samples and due to the instability of DNA lesions. Hemoglobin appears to

1 Department of Radiobiology, Stockholm University, Wallenberg Laboratory, S-106 91 Stockholm, Sweden.

- Medical Research Council Toxicology Unit, Medical Research Council Laboratories, Woodmansterne Road, Carshalton, Surrey SM5 4EF, England.

Reprint requests to: Dr S Osterman-Golkar, Department of Radiobiology, Stockholm University, Wallenberg Laboratory, S-106 91 Stockholm, Sweden. be a suitable monitor molecule and is easily obtained in large quantities. The life-span (approximately 18 weeks in man) of hemoglobin (and the red cell) is not affected by low degrees of alkylation, and therefore stable reaction products accumulate in a predictable way during prolonged exposure $(11,13)$.

The present communication reports on the dosimetry of propylene oxide by the analysis of $N^{T}$-(2hydroxypropyl)histidine in hemoglobin from a group of workers exposed to this compound and from a reference group.

\section{Material and methods}

The exposed individuals were employed in a factory where propylene oxide was used for the production of hydroxypropylated starch. The same subjects were also assayed for micronuclei in lymphocytes (B Högstedt, unpublished data) and with respect to unscheduled DNA synthesis in peripheral lymphocytes treated in vitro with $\mathrm{N}$-acetoxy-2-acetylaminofluorene (12). A monitoring of air concentrations of propylene oxide was performed during five workdays in connection with the biological monitoring and was both personal and stationary.

The radiolabeled internal standard of $N^{\top}$-(2hydroxypropyl)histidine was synthesized as follows: 1.8 MBq of ${ }^{14} \mathrm{C}$-labeled histidine (The Radiochemical Centre, Amersham, the United Kingdom) (specific activity $12.7 \mathrm{GBq} / \mathrm{mmol}$ ) was acetylated with 0.5 mmol of acetic anhydride in $2.5 \mathrm{ml}$ of acetic acid at $120^{\circ} \mathrm{C}$ for $30 \mathrm{~s}$. The reaction mixture was evaporated to dryness. Propylene oxide $(1.5 \mathrm{mmol})$ dissolved in 
$2 \mathrm{ml}$ of water was added and allowed to react for $24 \mathrm{~h}$ at room temperature. The solution was then evaporated to dryness, and the product was hydrolyzed in $4 \mathrm{M}$ hydrochloric acid $(2 \mathrm{ml})$ for $4 \mathrm{~h}$ at $90^{\circ} \mathrm{C}$. $N^{\mathrm{T}}$ - $(2$ hydroxypropyl)histidine was isolated by ion-exchange chromatography using the same method as that used for globin hydrolysates (see the next paragraph). The unlabeled and deuterium-labeled $N^{T}$ (2-hydroxypropyl)histidines were synthesized as described previously (2).

Blood samples were collected from nine workers exposed to propylene oxide from different departments of the plant, from four referents employed at an ethylene oxide sterilization plant, and from nine referents from the same geographic area as the workers exposed to propylene oxide. The samples were collected in heparinized vacutainer tubes with cannulae sterilized with gamma radiation. The samples were coded before the analysis of the hemoglobin alkylation. The red cells were spun down $(2,500 \mathrm{r} / \mathrm{min})$ and were carefully washed with saline. The cells were lyzed by the addition of an equal volume of water. Cell membranes and debris were sedimented by centrifugation at $20,000 \mathrm{~g}$ for $20 \mathrm{~min}$. The supernatant was dialyzed overnight against buffer $(1.0 \mathrm{~g}$ of ammonium chloride, $3.0 \mathrm{~g}$ of potassium dihydrogen phosphate, $6.0 \mathrm{~g}$ of disodium monohydrogen phosphate, and $0.27 \mathrm{~g}$ of magnesium sulfate heptahydrate per liter) and the protein was then hydrolyzed by the addition of enzymes $(20 \mathrm{mg}$ of hemoglobin $/ \mathrm{ml} ; 25 \mathrm{mg}$ of trypsin $4 \mathrm{~h}, 25 \mathrm{mg}$ of pronase $2 \times 3 \mathrm{~h}$ for the hydrolysis of $1 \mathrm{~g}$ of hemoglobin; $\left.37^{\circ} \mathrm{C}\right){ }^{3}$ Radiolabeled $N^{\top}$-(2-hydroxypropyl)histidine $(10,000$ detectable pulses per minute/sample; $0.003 \mathrm{nmol} / \mathrm{sample)}$ was added as a tracer and internal standard. The samples were acidified by the addition of $6 \mathrm{ml}$ of $4 \mathrm{M}$ hydrochloric acid to precipitate heme, filtered, and evaporated to dryness. The hydrolysates were applied to Dowex $50 \mathrm{~W}-\mathrm{X} 4$ columns $(22 \times 1.4 \mathrm{~cm})$ and eluted with $400 \mathrm{ml}$ of $1 \mathrm{M}$ hydrochloric acid (1 fraction) followed by $2 \mathrm{M}$ hydrochloric acid collected in 13-ml fractions. The fractions $(4-10)$ containing $N^{\top}$-(2-hydroxypropyl)histidine were evaporated and rechromatographed on an Aminex A-5 $(54 \times 0.9 \mathrm{~cm})$ column. This column

\footnotetext{
3 The method described by Calleman et al (1) involving precipitation of the globin by acetone-hydrochloric acid followed by hydrolysis in $6 \mathrm{M}$ hydrochloric acid proved to be unsuitable for the analysis of 2-hydroxypropylhistidine due to the presence of disturbing material in some of the samples for gas chromatography-mass spectrometry. Therefore the described procedure was employed in the present study. Later work has demonstrated that the problem with contamination is avoided if the globin is precipitated by an alternative method: $150 \mathrm{mg}$ of hemoglobin is dissolved in $7 \mathrm{ml}$ of water 2-propanol (1:6) containing $50 \mu 1$ of $6 \mathrm{M}$ hydrochloric acid. After centrifugation for $10 \mathrm{~min}$ at $5000 \mathrm{r} / \mathrm{min}$ globin is precipitated from the supernatant by the addition of $4 \mathrm{ml}$ of ethyl acetate. The precipitate is washed with ethyl acetate and pentane and dried in vacuum over concentrated sulfuric acid.
}

was eluted with $40 \mathrm{ml}$ of $0.1 \mathrm{M}$ sodium phosphate buffer $\mathrm{pH} 6.0$ followed by $0.1 \mathrm{M}$ sodium phosphate buffer $\mathrm{pH} 7.5$, which was collected in 6-ml fractions. The radioactivity peak (fractions 14-16) was collected and rechromatographed on a Dowex 50W-X4 (analytical grade) column $(80 \times 1 \mathrm{~cm})$ eluted with $2 \mathrm{M}$ hydrochloric acid. Fractions of $8 \mathrm{ml}$ were collected. Fractions 38-40 were pooled and evaporated to dryness for the determination of $N^{\top}$-(2-hydroxypropyl)histidine. [The $80-\mathrm{cm}$ column was needed in order to separate $N^{\top}$-(2-hydroxypropyl)histidine from $N^{\top}$-(2hydroxyethyl)histidine (fractions $33-35$ ), which was determined in the same globin samples. The quantitative data for $N^{\top}$-(2-hydroxyethyl)histidine will be presented elsewhere.]

Extracts containing $N^{\top}$-(2-hydroxypropyl)histidine were dissolved in $0.1 \mathrm{M}$ hydrochloric acid, and an aliquot was taken for radioactivity counting in order to determine the recovery of the alkylated amino acid in the isolation procedure up to this stage. The amount of $N^{\top}$-(2-hydroxypropyl)histidine in the remaining solutions was determined by high resolution gas chromatography-mass spectrometry (GCMS) essentially by the previously described method (9). In summary this procedure involved the following stages: addition of internal standard $\left({ }^{2} \mathrm{H}_{5} \mid-\right.$ $N^{\top}$-(2-hydroxypropyl)histidine, $30 \mathrm{ng}$ or $100 \mathrm{ng}$ ), removal of solvent, esterification with $3 \mathrm{M}$ hydrogen chloride in methanol and acylation with heptafluorobutanoic anhydride in dry ethyl acetate. All glassware used for the mass spectrometric determinations was washed with chromic acid and silanized. The resulting derivatives were analyzed by multiple ion detection using the ions $\mathrm{m} / \mathrm{z} 560 \mathrm{I}\left(\mathrm{M}-\mathrm{COOCH}_{3}\right)^{+}$, $\left|{ }^{2} \mathrm{H}_{0}\right| \mid$ and $\mathrm{m} / \mathrm{z} 565\left|\left(\mathrm{M}-\mathrm{COOCH}_{3}\right)^{+},\right|^{2} \mathrm{H}_{5}||$ for quantitation. The analysis was carried out on a VG analytical $70-70$ double focusing mass spectrometer coupled with a Pye Unicam 204 gas chromatograph. Some quantitations were confirmed by the analysis of the ions $\mathrm{m} / \mathrm{z} 619\left|\mathrm{M}^{+},\right|^{2} \mathrm{H}_{0}||$ and $\mathrm{m} / \mathrm{z} 624$ $\left|\mathrm{M}^{+},,\right|^{2} \mathrm{H}_{5}||$. The capillary column $(20 \mathrm{~m} \times 0.3$ $\mathrm{mm}$ ) used was of fused silica coated with SE-52 stationary phase.

Quantitation of $N^{\tau}$-(2-hydroxypropyl)histidine in the extracts at the point when the deuterium-labeled internal standard was added was made by a comparison of the determined $\left|{ }^{2} \mathrm{H}_{0}\right|:\left|{ }^{2} \mathrm{H}_{5}\right|$ peak height ratios from duplicate GC-MS analyses with those on a calibration curve. This curve was obtained from the analysis of mixtures of $\left.\right|^{2} \mathrm{H}_{0} \mid(0-30 \mathrm{ng}$ or $0-100 \mathrm{ng})$ and $\left|{ }^{2} \mathrm{H}_{5}\right|$ (30 ng or $100 \mathrm{ng}$ ) $N^{\tau}$-(2-hydroxypropyl)histidine. The use of the lower amount of internal standard $(30 \mathrm{ng})$ normally allowed levels of $\left.\right|^{2} \mathrm{H}_{0} \mid$ amino acid to be determined down to $2 \mathrm{ng} /$ protein sample. Below this amount results were inaccurate owing to background noise.

Radioactivity assays were made with a Beckman LS6800 liquid scintillation spectrometer. Samples 
were dissolved in Beckman Ready-Solv MP liquid scintillation solution.

\section{Results and discussion}

The previously described method (9) for the GC-MS analysis of $N^{\tau}$-(2-hydroxypropyl)histidine in globin was designed for use with protein samples of weight no greater than $10 \mathrm{mg}$. Only a minimal purification technique was used. More extensive purification of the alkylated amino acid derived from these larger amounts of hydrolyzed human globin is necessary in order to provide a sample sufficiently free of contamination for GC-MS analysis. The currently described procedure gave very satisfactory quantitations, an example of which is illustrated in figure 1, which shows a selected ion monitor trace from the analysis of a sample from worker number 1 . In order to achieve maximum sensitivity, only one pair of ions

Figure 1. Selected ion monitor trace $(\mathrm{m} / \mathrm{z} 560$ and $\mathrm{m} / \mathrm{z} 565)$ of an extract from the hemoglobin obtained from a worker (number 1) exposed to propylene oxide. ${ }^{2} \mathrm{H}_{5}$ l-labeled internal standard $(100 \mathrm{ng})$ was added. The gas chromatographic-mass spectrometric conditions were as described by Farmer et al (9). The determined level of $N^{\top}$-(2-hydroxypropyl)histidine in the globin was $13 \mathrm{nmol} / \mathrm{g}$.

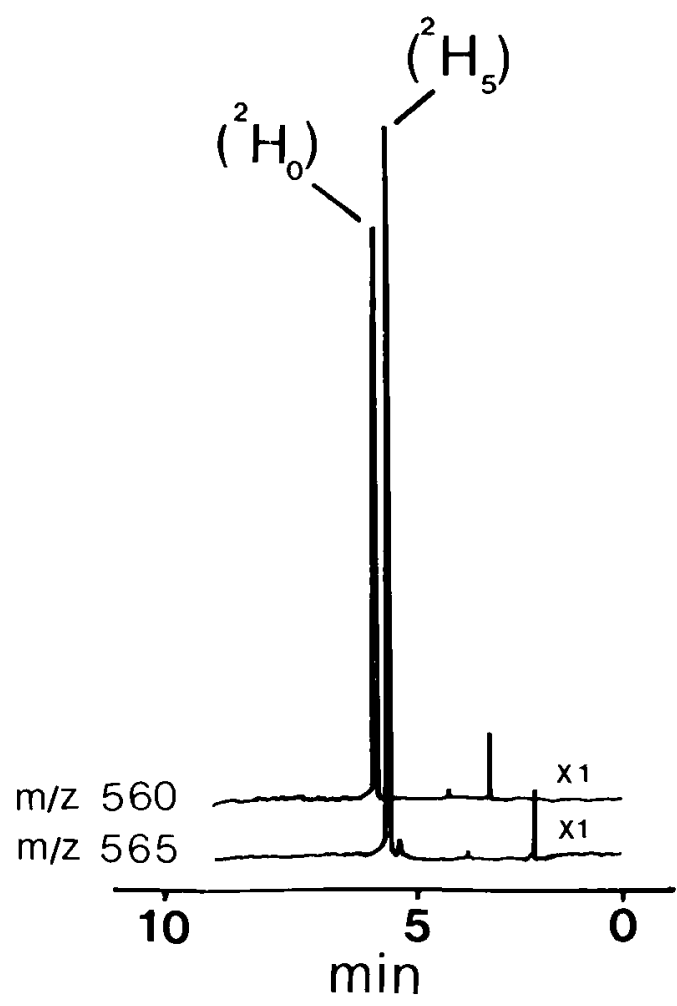

Table 1. Degree of alkylation of $N^{\top}$-(2-hydroxypropyl)histidine (HOPrHis) in hemoglobin (Hb) from workers exposed to propylene oxide $(\mathrm{PO})$ and from referents.

\begin{tabular}{|c|c|c|c|}
\hline \multirow[b]{2}{*}{ Group } & \multicolumn{2}{|r|}{ Exposure data } & \multirow[b]{2}{*}{$\begin{array}{l}\text { Degree of alkylation } \\
\text { of hemoglobin } \\
\text { (nmol HOPrHis/g Hb) }\end{array}$} \\
\hline & $\begin{array}{l}\text { Level of } \\
\text { exposure }\end{array}$ & $\begin{array}{c}\text { Workdays } \\
\text { with PO exposure } \\
\text { (December 1980-February 1981a) }\end{array}$ & \\
\hline
\end{tabular}

Employees/workers exposed to PO

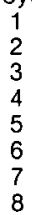

1
2
3
4
5
6
7
8

Employees of an ethylene oxide sterilization plant

$\begin{array}{ll}9 & 0 \\ 10 & 0 \\ 11 & 0 \\ 12 & 0\end{array}$

Residents from the same geographic area as the workers exposed to PO

13
14
15
16
17
18
19
20
21

$\begin{array}{lcc}\text { High } & 43 & 7.3 ; 13^{\mathrm{b}} \\ \text { High } & 47 & <8.6 ; 4.1^{\mathrm{b}} \\ \text { High } & 16 & 4.5 ; 6.8^{\mathrm{b}} \\ \text { High } & 17 & 6.7 \\ \text { Intermediate } & 37 & 1.0 \\ \text { Intermediate } & 44 & 1.2 \\ \text { Low } & 20 & 0.85 \\ \text { e } & 0 & 0.2\end{array}$

$\begin{array}{lcc}0 & 0.2^{f} \\ 0 & \cdot & 0.1 \\ 0 & \cdot & 0.38 \\ 0 & \cdot & <0.1\end{array}$

$\begin{array}{lll}0 & : & <0.1 \\ 0 & : & <0.1 \\ 0 & : & <0.1 \\ 0 & : & <0.1 \\ 0 & : & <0.1 \\ 0 & : & <0.1 \\ 0 & : & <0.1 \\ 0 & : & <0.1 \\ 0 & \end{array}$

The blood sampling was undertaken the week beginning 10 March 1981.

Analyses of protein samples that have been worked up independently.

c The same workplace as number 3; personal monitoring of this worker suggested that the exposure should be classified as intermediate (sampling time $191 \mathrm{~min}$; concentration range $0.5-1.4 \mathrm{ppm}$, mean concentration $1.1 \mathrm{ppm}$ ).

d Low average air levels were recorded, 0.2 and $<0.3 \mathrm{ppm}$, on two different occasions.

e Not at work during the year preceding blood sampling.

$f$ inaccurate value; less than $2 \mathrm{ng}$ in the protein sample. 
$\left[\mathrm{m} / \mathrm{z} 560,\left(\mathrm{M}-\mathrm{COOCH}_{3}\right)^{+},{ }^{2} \mid \mathrm{H}_{0}\right.$ and $\mathrm{m} / \mathrm{z}, 565$, $\left.\left(\mathrm{M}-\mathrm{COOCH}_{3}\right)^{+},{ }^{2} \mid \mathrm{H}_{5}\right]$ was normally monitored. For several analyses the specificity of the method was checked by the additional monitoring of a second pair of ions $\left[\mathrm{m} / \mathrm{z} 619, \mathrm{M}^{+},{ }^{2}|\mathrm{H}|_{0}\right.$, and $\mathrm{m} / \mathrm{z} 624$, $\left.\mathrm{M}^{+},{ }^{2} \mid \mathrm{HI}_{5}\right]$. Similar isotope ratios were obtained from both pairs of ions.

The results of the analyses of alkylation of histidine- $N^{\top}$ in hemoglobin from workers exposed to propylene oxide and referents are presented in table 1 together with exposure data. At the time when the samples were collected the hygienic standard for propylene oxide in Sweden was $10 \mathrm{ppm}$. The timeweighted average air concentrations for the most exposed workers were close to this value during propylene oxide-exposing processes $(25-75 \%$ of the work time). However, due to the large variations observed in the air concentrations of different locations in the plant and at different times in the processing of the starch and due to differences in the work methods, it is difficult to estimate reliable exposure doses for individual workers from these measurements.

The degree of alkylation of hemoglobin gives a measure of the in vivo dose obtained during a period of about four months (the life-span of red cells; see the Introduction). The determination of hemoglobin alkylation is therefore superior to point measurements of concentrations for the surveillance of exposure conditions in work environments. For the purpose of comparison with data on hemoglobin alkylation the exposures were classified as high, intermediate, and low on the basis of air concentrations and duration of exposure. Good agreement was obtained between the estimated exposure and hemoglobin alkylation. One of the workers assigned as exposed (number 8) had a very low degree of alkylation of hemoglobin. It was discovered that he had been unexposed during the year preceding the blood sampling. In the present study he could therefore be regarded as a referent.

The present study demonstrates that the method used is sensitive enough for dosimetry to be carried out at current exposure levels in some work environments. Levels on the order of magnitude of $0.1 \mathrm{nmol}$ $N^{\top}$-(2-hydroxypropyl)histidine/g of hemoglobin are indicated in hemoglobin from some nonexposed workers. Where such backgrounds exist the possibility of identifying long-term propylene oxide exposures at levels considerably lower than those encountered in this study may be limited.

\section{Acknowledgments}

The study was supported financially by the Swedish Work Environment Fund and the British Medical Research Council.
Thanks are due to Ms E Richardson for her skillful technical assistance.

\section{References}

1. Calleman CJ, Ehrenberg L, Jansson B, OstermanGolkar S, Segerbäck D, Svensson K, Wachtmeister CA. Monitoring and risk assessment by means of alkyl groups in hemoglobin in persons occupationally exposed to ethylene oxide. J Environ Pathol Toxicol 2 (1978) 427-442.

2. Campbell JB. The synthesis of $N(\tau)$-2'-hydroxypropylhistidine, $N(\tau)-2^{\prime}$-hydroxyethylhistidine, and their deuterated analogues. J Chem Soc Perkin Trans 1 (1983) 1213-1217.

3. Dunkelberg $\mathbf{H}$. On the oncogenic activity of ethylene oxide and propylene oxide in mice. Br J Cancer 39 (1979) $588-589$.

4. Dunkelberg H. Carcinogenic activity of ethylene oxide in comparison with 1,2-propylene oxide after subcutaneous administration in mice. Zbl Bakt Hyg (I Abt Orig B) 174 (1981) 383-404.

5. Dunkelberg $\mathrm{H}$. Carcinogenicity of ethylene oxide and 1,2-propylene oxide upon intragastric administration to rats. Br J Cancer 46 (1982) 924-933.

6. Ehrenberg L, Hiesche KD, Osterman-Golkar S, Wennberg I. Evaluation of genetic risks of alkylating agents: Tissue doses in the mouse from air contaminated with ethylene oxide. Mutat Res 24 (1974) 83-103.

7. Ehrenberg L, Hussain S. Genetic toxicity of some important epoxides. Mutat Res 86 (1981) 1-113.

8. Ehrenberg L, Osterman-Golkar S. Alkylation of macromolecules for detecting mutagenic agents. Teratogenesis carcinog mutagenesis 1 (1980) 105-127.

9. Farmer PB, Gorf SM, Bailey E. Determination of hydroxypropylhistidine in hemoglobin as a measure of exposure to propylene oxide using high resolution gas chromatography/mass spectrometry. Biomed Mass Spectrom 9 (1982) 69-71.

10. Hussain SS. Mutagenic action of radiation and chemicals: Parameters affecting the response of test systems. Stockholm University, Stockholm 1981. (Doctoral dissertation).

11. Osterman-Golkar S, Ehrenberg L, Segerbäck D, Hällström I. Evaluation of genetic risks of alkylating agents: II Haemoglobin as a dose monitor. Mutat Res 34 (1976) $1-10$.

12. Pero RW, Brungelsson T, Widegren B, Högstedt $B$, Welinder $H$. A reduced capacity for unscheduled DNA-synthesis in lymphocytes from individuals exposed to propylene oxide and ethylene oxide. Mutat Res 104 (1982) 193-200.

13. Segerbäck D, Calleman CJ, Ehrenberg L, Löfroth G, Osterman-Golkar S. Evaluation of genetic risks of alkylating agents: IV Quantitative determination of alkylated amino acids in hemoglobin as a measure of the dose after treatment of mice with methyl methanesulfonate. Mutat Res 49 (1978) $71-82$.

14. Walpole AL. Carcinogenic action of alkylating agents. Ann NY Acad Sci 68 (1957) 750-761. 